\title{
Analisa Proses Perpindahan Panas pada Pengecoran Paduan Al-12\%Si dengan Metode Elemen Hingga
}

\author{
Muhammad Bahtiyar Firdaus, Mas Irfan P. Hidayat, Dian Mughni Fellicia \\ Teknik Material dan Metalurgi, Fakultas Teknologi Industri, Institut Teknologi Sepuluh Nopember (ITS) \\ Jl. Arief Rahman Hakim, Surabaya 60111 Indonesia \\ e-mail: irfan@mat-eng.its.ac.id
}

\begin{abstract}
Abstrak-Piston merupakan salah satu komponen yang sangat penting bagi sebuah kendaraan. Di dalam sebuah industri, pembuatan piston dilakukan dengan cara pengecoran atau casting. Dalam proses pengecoran terdapat banyak fenomena umum yang tidak dapat dikontrol secara langsung seperti distribusi temperatur, tegangan termal, penyusutan serta deformasi cetakan. Oleh karena itu digunakan ANSYS Mechanical APDL yang berbasis metode elemen hingga untuk memprediksi fenomena dalam proses pengecoran. Digunakan pasir silika sebagai cetakan pasir dan SS304 sebagai permanent mold. Bahan coran yang digunakan adalah AL-12\% Si. Ukuran piston Ninja 250R dijadikan referensi pada simulasi ini dimana memiliki dimensi bore dan stroke sebesar $62 \mathrm{~mm}$ dan $41.2 \mathrm{~mm}$. Di dalam penelitian ini didapatkan pola distribusi temperatur serta tegangan termal dan juga shrinkage yang terjadi selama proses pengecoran dari kedua cetakan tersebut. Didapatkan nilai tegangan termal maksimum serta shrinkage sebesar 3.89E+09 Pa dan $31135.5 \mathrm{~mm}^{3}$ pada keseluruhan cetakan SS304 sedangkan pada keseluruhan cetakan pasir adalah $2.35 \mathrm{E}+08$ Pa dan 600 $\mathrm{mm}^{3}$. Untuk bagian coran nilai tegangan termal maksimum dan shrinkage pada cetakan SS304 adalah 65228892.2 Pa dengang shrinkage sebesar $6.9457 \mathrm{~mm}^{3}$ dan pada cetakan pasir sebesar 258718.871 Pa dan $0.0245 \mathrm{~mm}^{3}$.
\end{abstract}

Kata Kunci-Al-12\%Si, analisa elemen hingga, distribusi temperatur, pengecoran, shrinkage, tegangan termal

\section{PENDAHULUAN}

$\mathrm{T}$ ERDAPAT beberapa kesulitan untuk mengontrol hasil pengecoran pada piston karena sangat bergantung pada karakteristik lelehan logam yang sangat berhubungan dengan sifat-sifat termal serta struktur dari logam dan paduan yang digunakan. Dan juga banyak faktor lain seperti kelarutan gas, material dan bentuk dari cetakan (mold) itu sendiri yang akan berpengaruh pada munculnya fenomena-fenomena yang terjadi di dalam pengecoran [1].

Salah satu fenomena yang terjadi di dalam pengecoran adalah tegangan termal yang merupakan tegangan yang berada di dalam suatu benda sebagai akibat dari perubahan temperatur. Tegangan termal ini dapat menyebabkan patahan serta deformasi plastis di dalam suatu benda. Dimisalkan saja suatu batang solid yang homogen serta isotropi, ketika dipanaskan ataupun didinginkan maka panas yang terjadi akan merata ke seluruh bidang sehingga tidak terjadi gradien temperatur [2].

Kemudian fenomena lainnya di dalam proses pengecoran adalah shrinkage yang muncul selama proses solidifikasi dikarenakan perbedaan volumetrik antara fasa solid dengan liquid. Di dalam paduan aluminium, shrinkage yang muncul selama proses solidifikasi memiliki rentang sekitar 3.5 sampai $8.5 \%$. Kecenderungan untuk terbentuknya shrinkage berhubungan dengan fraksi volume pada akhir solidifikasi dan rentang temperatur solidifikasi dari paduan itu sendiri [3].

Dengan banyaknya fenomena yang terjadi di dalam pengecoran, maka diperlukan sebuah pemodelan untuk menganalisa fenomena yang terjadi di dalam pengecoran. Software yang berbasis metode elemen hingga dapat meneliti fenomena yang ada selama pengecoran. Seperti Pariona dkk yang meneliti tentang simulasi numerik perpindahan panas selama solidifikasi dari besi murni dengan cetakan berbahan pasir serta berbahan mullite [4]. Kemudian Sunanda dkk yang melakukan penelitian tentang analisa desain dari pengecoran besi murni dengan bahan cetakan yang berbeda yaitu cetakan berbahan pasir silika, berbahan mullite dan cetakan berbahan komposit pasir silika dengan mullite [1].

Untuk menyempurnakan penelitian di atas maka dilakukan penelitian lanjutan yang bertujuan untuk membandingkan dua jenis cetakan pengecoran dengan bahan SS304 serta pasir silika. Kemudian menganalisa fenomena yang ada seperti distribusi temperatur, tegangan termal serta shrinkage yang terjadi selama proses pengecoran yang berhubungan dengan ketahanan cetakan serta hasil dari pengecoran itu sendiri dengan pemodelan secara 3 dimensi.

\section{METODE PENELITIAN}

Al-12\%Si digunakan sebagai material coran dikarenakan paduan Al-Si ini memiliki sifat mampu cor dan mampu alir yang sangat baik, mempunyai permukaan yang bagus, memiliki ketahanan korosi yang baik, berat jenisnya ringan, serta pada titik eutektik $850 \mathrm{~K}$, paduan $\mathrm{Al}-12 \% \mathrm{Si}$ memiliki titik cair yang rendah sehingga cocok untuk dijadikan sebagai paduan tuang [5].

Kemudian untuk jenis cetakan dibedakan menjadi dua jenis yaitu cetakan SS304 yang berbahan SS304 serta cetakan pasir dengan bahan pasir silika.

Digunakan satu buah geometri yaitu gabungan antara material coran dengan cetakan. Untuk material coran sendiri mengacu pada dimensi dari piston sepeda motor Ninja 250R dengan panjang piston $6,2 \mathrm{~cm}$ dan lebar sebesar $41,2 \mathrm{~cm}$ [6] yang dibuat dengan aplikasi SolidWorks 2014 x64 Edition yang kemudian dimasukkan ke dalam ANSYS Mechanical APDL 
17.0 menggunakan format parasolid. Gambar geometri dapat dilihat pada gambar 1 .

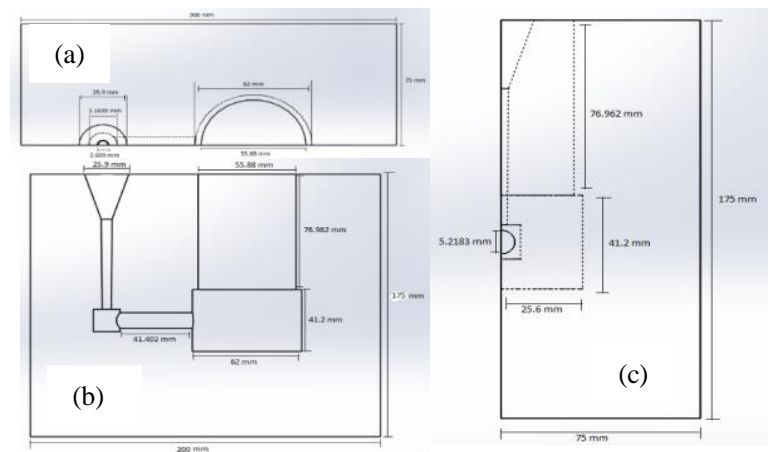

Gambar 1. Geometri Cetakan dan Material Coran (a) tampak depan (b) tampak atas (c) tampak samping

Tipe elemen yang digunakan pada penelitian ini adalah SOLID278 (brick 8node 278) untuk analisa termal dikarenakan tipe elemen ini memiliki kapabilitas di dalam konduksi termal tiga dimensi. Elemen ini memiliki 8 nodal dengan 1 buah derajat kebebasan dan temperatur setiap nodal.

Kemudian untuk menganalisa struktural, digunakan elemen SOLID227 dikarenakan elemen ini dapat digunakan dalam analisa couple-field dari termal ke struktural. Elemen ini memiliki 8 nodal dengan 7 derajat kebebasan.

Setelah menentukan elemen, langah selanjutnya adalah melakukan meshing dengan ukuran 0.004 untuk material coran serta ukuran 0.008 untuk material cetakan.

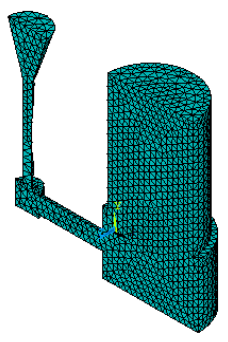

(a)

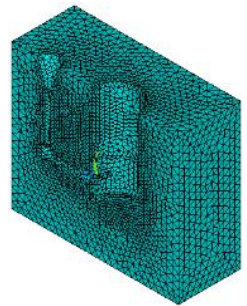

(b)

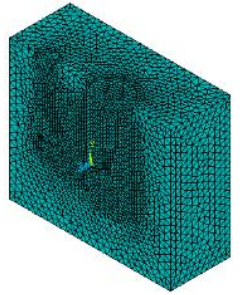

(c)
Gambar 2. a. Meshing dari Material Coran Al-12\%Si b. Meshing dari Material Cetakan (Cetakan Pasir \& SS304) c. Meshing Gabungan Antara Cetakan dengan $\mathrm{Al}-12 \% \mathrm{Si}$

Hasil dari meshing dapat dilihat pada gambar 2 dimana pada gambar a menunjukkan meshing dari material coran $\mathrm{Al}-12 \% \mathrm{Si}$, $\mathrm{b}$ menunjukkan meshing dari cetakan dan c menunjukkan gabungan meshing dari material coran dengan cetakannya.

Boundary condition yang digunakan dalam penelitian ini adalah konveksi yang diletakkan pada bagian luar cetakan dimana akan berpengaruh kepada distribusi temperatur. Kemudian dianggap tidak ada inklusi benda asing di dalam rongga cetak, material cetakan serta material coran dianggap homogen, bagian dasar cetakan dianggap menyentuh tanah sehingga tidak terjadi konveksi serta pengamatan berfokus pada fenomena yang terjadi pada riser dan rongga cetak.

Kemudian, pembebanan dilakukan ke dalam geometri yang telah di-meshing. Dengan pengaturan seperti pada tabel 1.
Tabel 1.

Pengaturan pada pengecoran

\begin{tabular}{c|c}
\hline \hline Total Waktu Simulasi & 5400 detik atau $1.5 \mathrm{jam}$ \\
\hline Time Step & 60 detik \\
Temperatur awal coran & $963 \mathrm{~K}$ \\
Temperatur awal cetakan & $303 \mathrm{~K}$ \\
Nilai konveksi & $11.45 \mathrm{~W} / \mathrm{m}^{2} \mathrm{~K}$ \\
\hline
\end{tabular}

Waktu pendinginan yang ditentukan adalah 1.5 jam atau 5400 detik dengan time step per 60 detik yang berarti ANSYS akan mencatat hasil analisa setiap 60 detik. Temperatur awal coran ditentukan sebesar $963 \mathrm{~K}$ sesuai dengan penelitian yang dilakukan Xin-Ping pada tahun 2011 yang meneliti tentang efek dari selftempering di dekat titik eutektik $\mathrm{Al}-\mathrm{Si}$ dengan ketebalan dinding berbeda di dalam cetakan permanen. Dan untuk nilai konveksi diambil dari penelitian yang dilakukan oleh Pariona pada tahun 2005. Temperatur awal ditentukan sebesar 303K yang merupakan temperatur kamar.

Temperatur sebesar 963K diaplikasikan ke dalam geometri coran. Dan temperatur sebesar 303K diaplikasikan ke dalam cetakan.

\section{HASIL DAN PEMBAHASAN}

\section{A. Distribusi Temperatur}

Model yang ditampilkan pada penelitian ini merupakan setengah cetakan agar mempermudah proses analisa fenomena yang terjadi selama pengecoran. Hasil dari distribusi temperatur pada cetakan SS304 ditampilkan pada gambar 3. Sedangkan untuk hasil dari distribusi temperatur pada cetakan pasir ditampilkan pada gambar 4.
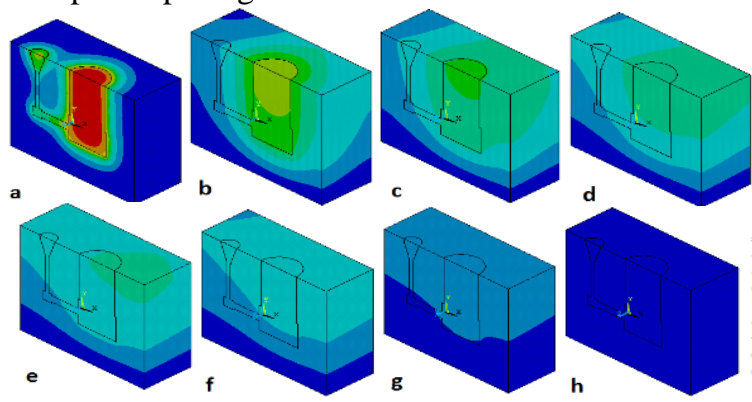

Gambar 3. Distribusi Temperatur Cetakan SS304 pada (a) 60 detik (b) 360 detik (c) 660 detik (d) 960 detik (e) 1260 detik (f) 1800 detik (g) 3600 detik (h) 5400 detik

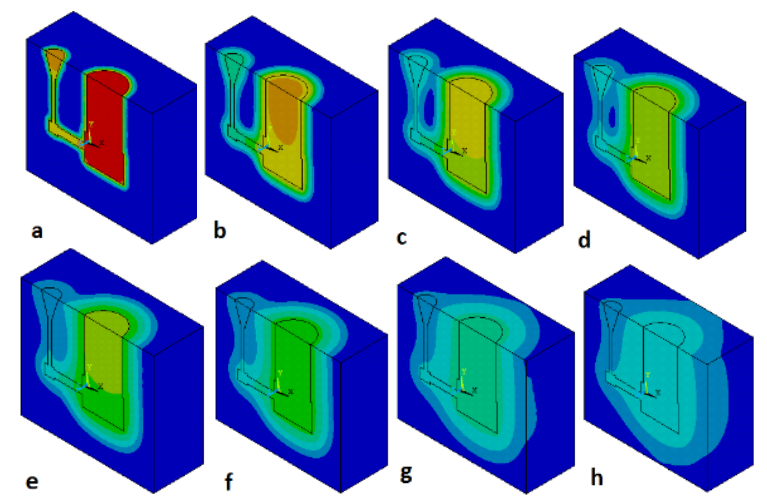

Gambar 4. Distribusi Temperatur Cetakan Pasir pada (a) 60 detik (b) 360 detik (c) 660 detik (d) 960 detik (e) 1260 detik (f) 1800 detik (g) 3600 detik (h) 5400 detik 
Dapat dilihat bahwa temperatur akan lebih mudah menyebar pada cetakan SS304. Perbedaan distribusi temperatur yang signifikan ini disebabkan oleh sifat dari material cetakan. Cetakan SS304 memiliki konduktifitas termal yang lebih tinggi, oleh karena itu cetakan SS304 memiliki kemampuan yang lebih baik untuk menyebarkan panas sehingga panas dari coran dapat dengan cepat menyebar ke dalam cetakan sebelum semuanya akan keluar menuju lingkungan sehingga dapat disimpulkan bahwa kecepatan pendinginan dari pengecoran dengan cetakan SS304 lebih besar daripada cetakan pasir.

Hal lain yang menyebabkan perbedaan distribusi temperatur ini adalah kapasitas panas dari cetakan. Diketahui bahwa kapasitas panas spesifik dari cetakan pasir jauh lebih besar dari cetakan SS304 yang menyebabkan peningkatan temperatur pada cetakan pasir relatif kecil. Dan juga cetakan pasir akan lebih sulit untuk menyerap panas dari coran.

Kemudian untuk melihat proses pendinginan pada coran diambil satu titik di dalam bagian coran baik pada cetakan SS304 serta cetakan pasir yang kemudian dibuat kurva yang dapat dilihat pada gambar 5 dan gambar 6 .

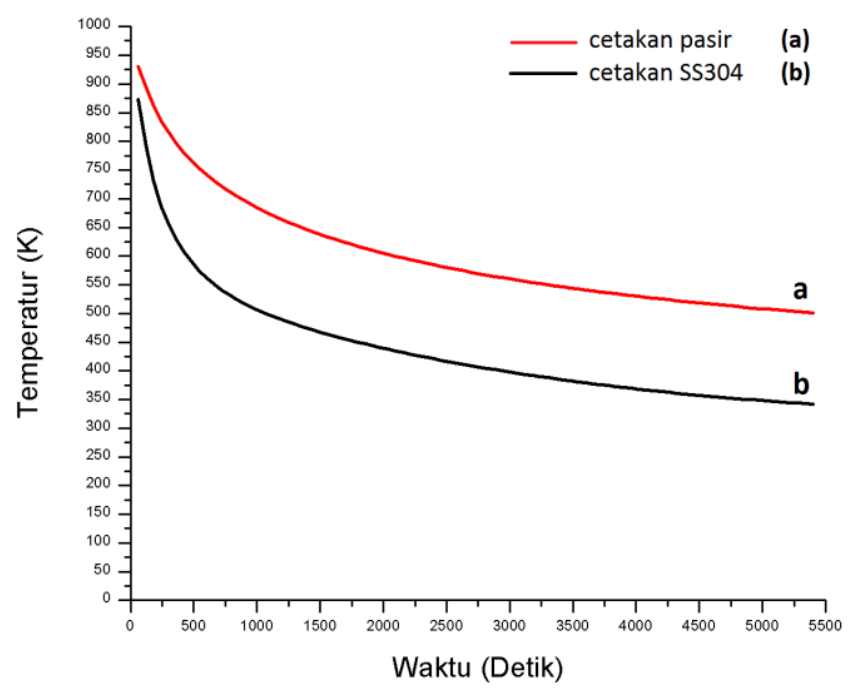

Gambar 5. Kurva perbandingan penurunan temperatur di dalam coran selama pendinginan pada cetakan SS304 serta cetakan pasir

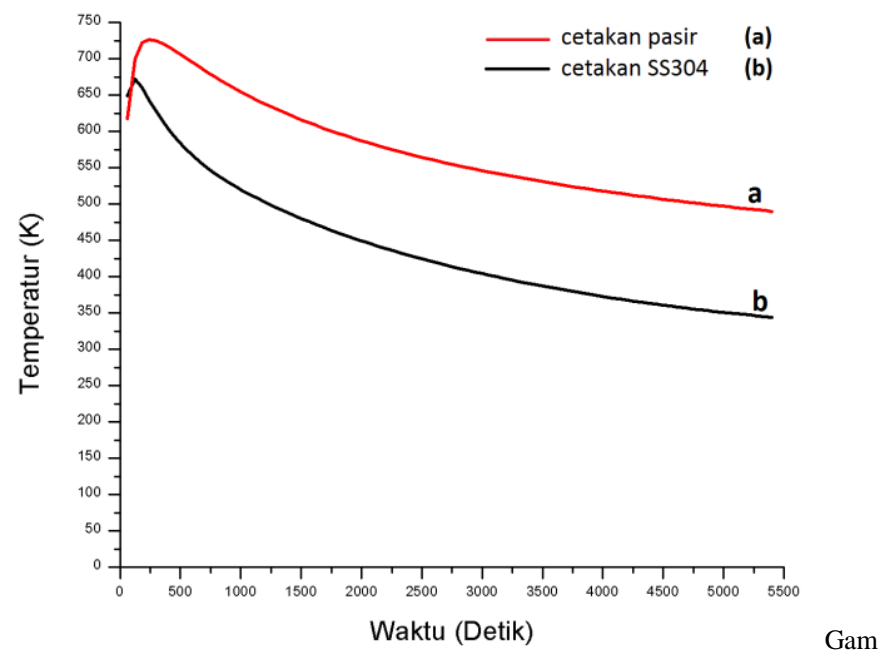

Gambar 6. Kurva perbandingan penurunan temperatur di dalam cetakan selama pendinginan pada cetakan SS304 serta cetakan pasir
Pada gambar tersebut diketahui bahwa kemiringan atau gradien kurva pendinginan dari cetakan pasir lebih landai dibandingkan cetakan SS304 yang berarti pendinginan pada cetakan pasir lebih lambat dibandingkan dengan cetakan SS304.

Yang menarik di sini adalah kurva pada daerah cetakan dimana bahwa temperatur dari cetakan naik sampai waktu dan temperatur tertentu yang disebabkan perambatan panas dari material coran. Suatu cetakan masih akan mengalami pertambahan panas apabila masih ada panas berlebih dari coran. Kemudian akan mulai turun ketika temperatur antara coran dengan cetakan sama yang kemudian temperatur turun setelah tidak ada input panas dari coran diamana pada saat itu panas yang berada di dalam cetakan akan disebar ke luar lingkungan.

\section{B. Gradien Temperatur}

Gradien temperatur adalah rentang perubahan temperatur di dalam suatu sistem. Di dalam simulasi ini, gradien temperatur yang terbentuk menggambarkan arah mulainya pendinginan dan dapat dilihat pada gambar 7 .

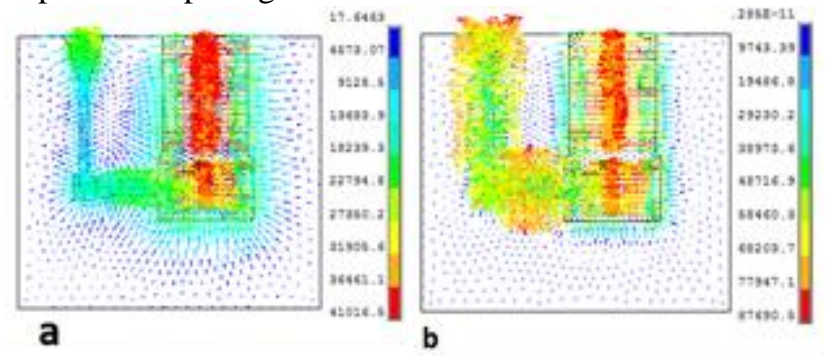

Gambar 7. Gradien temperatur pada (a) dengan cetakan SS304 (b) dengan cetakan pasir pada detik ke 60

Dapat diketahui bahwa arah gradien temperatur mengarah ke atas menuju material coran yang berarti arah pendinginan juga menuju material coran sama seperti yang telah kita bahas pada distribusi temperatur.

\section{Tegangan Termal}

Tegangan termal merupakan tegangan yang terjadi dikarenakan perubahan temperatur di dalam suatu material. Tegangan ini dipengaruhi oleh beberapa sifat material yaitu modulus elastisitas suatu material, koefisien ekspansi termal serta perbedaan temperatur pada suatu material [2].

Nilai tegangan termal yang didapat pada pemodelan ini ditampilkan pada tabel 2 .

Tabel 2.

Perbandingan Nilai Tegangan Termal antara Cetakan SS304 dengan Cetakan Pasir di Berbagai Waktu

\begin{tabular}{ccccc}
\hline \hline Waktu & & \multicolumn{3}{c}{ Jenis Cetakan } \\
(Detik) & SS304 & Pasir & Coran SS304 & Coran Pasir \\
\hline 60 & $2.28 \mathrm{E}+09 \mathrm{~Pa}$ & $1.2 \mathrm{E}+08 \mathrm{~Pa}$ & $19922796.3 \mathrm{~Pa}$ & $39317.8775 \mathrm{~Pa}$ \\
960 & $3.38 \mathrm{E}+09 \mathrm{~Pa}$ & $1.79 \mathrm{E}+08 \mathrm{~Pa}$ & $83539696.3 \mathrm{~Pa}$ & $71006.3619 \mathrm{~Pa}$ \\
1860 & $3.54 \mathrm{E}+09 \mathrm{~Pa}$ & $1.99 \mathrm{E}+08 \mathrm{~Pa}$ & $75799079.5 \mathrm{~Pa}$ & $105314.74 \mathrm{~Pa}$ \\
2760 & $3.66 \mathrm{E}+09 \mathrm{~Pa}$ & $2.12 \mathrm{E}+08 \mathrm{~Pa}$ & $70636066.7 \mathrm{~Pa}$ & $144057.54 \mathrm{~Pa}$ \\
3660 & $3.76 \mathrm{E}+09 \mathrm{~Pa}$ & $2.21 \mathrm{E}+08 \mathrm{~Pa}$ & $67639227 \mathrm{~Pa}$ & $183336.46 \mathrm{~Pa}$ \\
4560 & $3.84 \mathrm{E}+09 \mathrm{~Pa}$ & $2.29 \mathrm{E}+08 \mathrm{~Pa}$ & $66012923.5 \mathrm{~Pa}$ & $222457.658 \mathrm{~Pa}$ \\
5400 & $3.89 \mathrm{E}+09 \mathrm{~Pa}$ & $2.35 \mathrm{E}+08 \mathrm{~Pa}$ & $65228892.2 \mathrm{~Pa}$ & $258718.871 \mathrm{~Pa}$ \\
\hline \hline
\end{tabular}


Dapat disimpulkan bahwa nilai dari tegangan termal pada cetakan SS304 lebih tinggi daripada cetakan pasir.

\section{Shrinkage}

Shrinkage merupakan penyusutan volume di selama proses pengecoran. Hal ini menyebabkan volume dari suatu benda akan menyusut setelah dilakukan pendinginan sehingga benda yang dihasilkan tidak sesuai dimensinya dengan yang diharapkan [8].

Setelah dilakukan simulasi, baik material coran dengan cetakan mengalami deformasi yaitu berupa penyusutan. Hal ini mengakibatkan volume dari cetakan maupun coran menjadi berkurang. Hal ini disebabkan oleh tegangan termal yang ada di dalam suatu proses pengecoran yang telah kita bahas sebelumnya. Karena tegangan termal tersebut, akan terjadi shrinkage di dalam coran.

Untuk menghitung shrinkage yang terjadi selama simulasi, maka dicari terlebih dahulu nilai deformasi pada setiap sumbu. Kemudian geometri awal dikurangi dengan deformasi yang ada sesuai sumbunya. Setelah itu dilanjutkan dengan mnghitung volume akhir dari geometri tersebut. Dengan mengurangi volume awal dengan volume akhir yang telah dihitung tadi. Sehingga nilai shrinkage yang telah dihitung dapat dilihat pada tabel 3 .

Tabel 3.

Shrinkage maksimum yang terjadi selama proses pengecoran

\begin{tabular}{cc}
\hline \hline Material & Shrinkage yang terjadi $\left(\mathrm{mm}^{3}\right)$ \\
\hline Keseluruhan cetakan SS304 & $31135.5 \mathrm{~mm}^{3}$ \\
Keseluruhan cetakan pasir & $600 \mathrm{~mm}^{3}$ \\
Coran pada cetakan SS304 & $6.9457 \mathrm{~mm}^{3}$ \\
Coran pada cetakan pasir & $0.0245 \mathrm{~mm}^{3}$ \\
\hline \hline
\end{tabular}

\section{E. Massa Jenis}

Untuk membuktikan adanya penyusutan juga dapat dilakukan dengan membandingkan massa jenis dengan volumenya. Selama pengecoran massa dari material coran dianggap tetap. Kemudian seiring dengan berjalannya waktu yaitu proses pendinginan, maka volume akan menyusut. Diketahui bahwa massa jenis adalah massa per volume. Sehingga secara teori apabila volume semakin menyusut maka massa jenis akan naik dikarenakan massa yang tetap. Massa di dalam coran didapat dengan merata-rata massa jenis yang telah diperoleh kemudian mengalikannya dengan volume coran yang ada. Massa yang didapat dijadikan sebagai patokan di dalam penelitian ini. Di dalam penelitian ini, massa $\mathrm{Al}-12 \% \mathrm{Si}$ yang didapat sebesar $0.84 \mathrm{~kg}$.

Berikut dapat dilihat pada tabel 4 beberapa data yang diperoleh selama simulasi pengecoran ini yang dibagi setiap 1080 detik agar dapat melihat shrinkage yang terjadi secara merata.

Tabel 4.

Volume Material Coran pada Berbagai Waktu

\begin{tabular}{ccc}
\hline \hline \multirow{2}{*}{ Waktu (detik) } & \multicolumn{2}{c}{ Volume Akhir $\left(\mathrm{mm}^{3}\right)$} \\
& Cetakan SS304 & Cetakan Pasir \\
\hline 0 & 312973.5112 & 312973.5112 \\
1080 & 312973.1331 & 312973.4867 \\
2160 & 312972.7017 & 312973.4867 \\
\hline \hline
\end{tabular}

\begin{tabular}{lll}
\hline \hline 3240 & 312972.4015 & 312973.4867 \\
4320 & 312972.1798 & 312973.4867 \\
5400 & 312972.0199 & 312973.4867 \\
\hline \hline
\end{tabular}

Kemudian dibuat kurva seperti pada gambar 7.

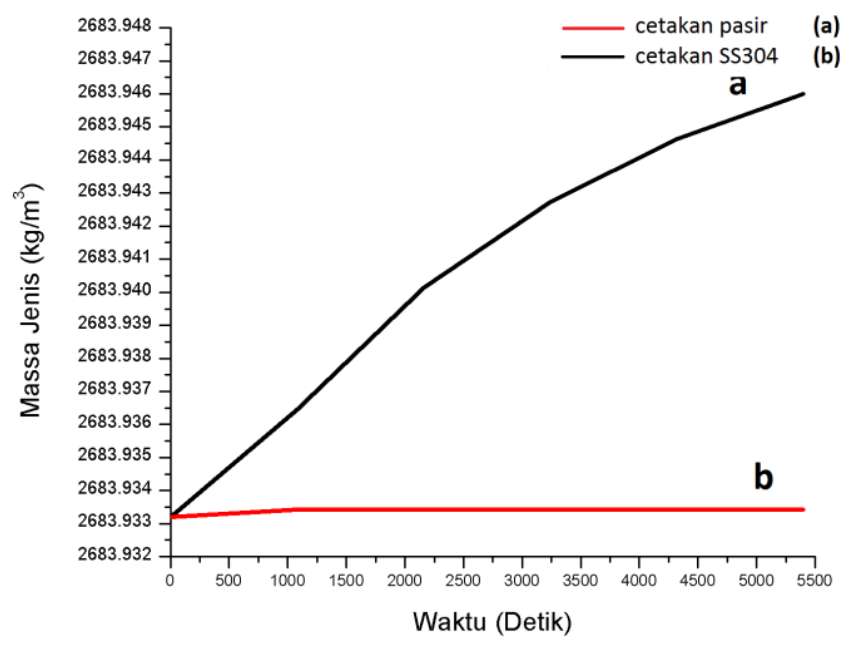

Gambar 7. Kurva Kenaikan Massa Jenis pada Coran

Dapat dilihat pada tabel beserta kurva tersebut, bahwa penyusutan volume di dalam coran pada cetakan SS304 semakin besar sesuai dengan bertambahnya waktu. Hal ini juga dialami oleh coran pada cetakan pasir. Namun, selisih penyusutan tiap waktu pada cetakan pasir sangatlah sedikit. Sehingga penyusutan tidak dapat dilihat di dalam kurva maupun tabel.

Dapat dilihat juga nilai penyusutan volume di dalam coran pada cetakan SS304 lebih tinggi dibandingkan dengan cetakan pasir. Hal ini berarti pada cetakan SS304 shrinkage yang terjadi lebih besar jika dibandingkan dengan shrinkage yang terjadi pada coran dengan cetakan pasir.

\section{F. Kualitas Cetakan}

Kualitas suatu cetakan sendiri tidak jauh dari efisiensi cetakan yang ada. Untuk melihat efisiensi serta kualitas dari suatu cetakan dapat menggunakan yield. Di dalam proses pengecoran, yield merupakan presentase dari massa atau volume coran yang baik dari semua logam yang dimasukkan. Dengan nilai yield yang tinggi maka logam yang harus dicairkan kembali akan lebih sedikit sehingga biaya untuk sebuah pengecoran menjadi lebih sedikit.

Berikut adalah formula untuk mencari nilai dari kualitas cetakan yang dapat dilihat dalam tabel 5 .

Tabel 5.

Formula Kualitas Cetakan Pengecoran [7][8]

\begin{tabular}{cc}
\hline \hline Jenis & Formula \\
\hline Quality & volume coran yang bebas dari shrinkage \\
\cline { 2 - 2 } Feeding & volume cetakan \\
Yield & volume cetakan \\
Feeding & $\begin{array}{c}\text { volume riser + volume riser } \\
\text { Efficiency }\end{array}$ \\
\hline \hline
\end{tabular}




\begin{tabular}{cc}
\hline \hline Gating & berat cetakan \\
Yield & berat cetakan + berat gating \\
Casting & Berat Cetakan \\
Yield & Berat Cetakan + Berat Riser + Berat Gating \\
\hline
\end{tabular}

Kemudian, sesuai dengan cetakan di dalam simulasi ini didapatkan nilai seperti ditampilkan pada tabel 6 .

Tabel 6.

Formula Kualitas Cetakan Pengecoran

\begin{tabular}{ccc}
\hline \hline \multirow{2}{*}{ Variabel } & \multicolumn{2}{c}{ Jenis Cetakan } \\
& $\mathrm{SS} 304$ & Cetakan Pasir \\
\hline Quality & $99.9 \%$ & $99.9 \%$ \\
Casting Yield & $39.6 \%$ & $39.6 \%$ \\
Gating Yield & $99 \%$ & $99 \%$ \\
Feeding Efficiency & $16.5 \%$ & $0.3 \%$ \\
Feeding Yield & $39.7 \%$ & $39.7 \%$ \\
\hline \hline
\end{tabular}

Dapat dilihat bahwa kualitas dari hasil coran baik pada cetakan pasir serta cetakan SS304 sebesar 99.9\%. Hal ini dapat diartikan bahwa cetakan tersebut memiliki kualitas yang sangat bagus, namun bukan berarti cetakan ini memiliki nilai efisiensi yang tinggi.

Dapat dikatakan bahwa daerah feeding serta daerah casting masih perlu dioptimisasi supaya lebih efisien dikarenakan nilai dari casting yield serta feeding yield yang masih rendah. Namun untuk gating yield, nilainya telah mencapai 99\% yang berarti gating system yang ada sudah bagus.

Kemudian feeding efisiensi dari cetakan SS304 masih berkisar $16.5 \%$ dan untuk cetakan pasir sebesar $0.3 \%$. Hal ini berarti riser yang ada hanya dapat mengisi sebesar $16.5 \%$ kekosongan yang disebabkan oleh shrinkage pada cetakan SS304 serta mengisi $0.3 \%$ kekosongan yang disebabkan oleh shrinkage pada cetakan pasir.

\section{G. Perbandingan Data}

Setelah melihat data di atas, kita dapat membandingkan bagaimana hasil dari pengecoran dengan cetakan SS304 serta cetakan pasir yang ditampilkan pada tabel 7 .

Tabel 7.

Perbandingan Data

\begin{tabular}{ccccc}
\hline \hline Jenis & \multicolumn{2}{c}{ Keseluruhan Cetakan } & \multicolumn{2}{c}{ Bagian Coran } \\
Cetakan & Shrinkage & $\begin{array}{c}\text { Tegangan } \\
\text { Termal } \\
\text { Maksimum }\end{array}$ & Shrinkage & $\begin{array}{c}\text { Tegangan } \\
\text { Termal } \\
\text { Maksimum }\end{array}$ \\
\hline SS304 & 31135.5 & $3.89 \mathrm{E}+09 \mathrm{~Pa}$ & 6.9457 & $\begin{array}{c}65228892.2 \\
\mathrm{~mm}^{3}\end{array}$ \\
& $\mathrm{~mm}^{3}$ & $\mathrm{~Pa}$ \\
Pasir & $600 \mathrm{~mm} 3$ & \multirow{2}{*}{$2.35 \mathrm{E}+08 \mathrm{~Pa}$} & 0.0245 & $\begin{array}{c}258718.871 \\
\mathrm{~mm}^{3}\end{array}$ \\
\hline \hline
\end{tabular}

Dari data di atas, dapat diketahui kekurangan dan kelebihan masing-masing cetakan. Cetakan SS304 memiliki kelebihan proses pendinginan yang lebih cepat dibandingkan cetakan pasir. Namun, cetakan SS304 ini memiliki kekurangan yaitu memiliki tegangan termal serta shrinkage yang lebih besar daripada cetakan pasir. Oleh karena itu, dapat disimpulkan bahwa cetakan pasir lebih cocok untuk mendapatkan hasil coran yang lebih bagus. Namun, apabila menginginkan kecepatan pendinginan yang cepat dapat digunakan cetakan SS304 sebagai pilihannya.

\section{KESIMPULAN}

.Dapat disimpulkan bahwa pada cetakan SS304, temperatur lebih cepat menyebar daripada cetakan pasir. Sehingga menyebabkan pendinginan di dalam cetakan SS304 berlangsung lebih cepat. . Pada daerah coran dengan cetakan SS304 didapatkan bahwa pada rentang 60 detik sampai 1260 detik terjadi penurunan temperatur dari $873 \mathrm{~K}$ menjadi $484 \mathrm{~K}$ sedangkan pada cetakan pasir sebesar $929 \mathrm{~K}$ menjadi $658 \mathrm{~K}$. Tegangan termal di dalam cetakan SS304 juga lebih besar daripada cetakan pasir dengan nilai 3.89E+09 Pa. Lebih besar daripada cetakan pasir yang sebesar $2.35 \mathrm{E}+08 \mathrm{~Pa}$ sehingga dapat disimpulkan bahwa distribusi temperatur sangat berpengaruh terhadap tegangan termal. Dengan kecepatan penyebaran yang tinggi maka tegangan termal juga semakin tinggi. Semakin tingginya tegangan termal maka shrinkage yang terjadi akan semakin besar. Dan untuk itu cetakan pasir lebih cocok dibandingkan cetakan SS304 dikarenakan shrinkage yang terjadi lebih kecil jika dibandingkan dengan cetakan SS304 sehingga dapat menghasilkan ceoran yang lebih baik.

\section{DAFTAR PUSTAKA}

[1] Das, Sunanda, dan Rakesh L. Himte. 2013. "Design \&Analysis of Pure Iron Casting with Different Moulds". International Journal of Modern Engineering Research (IJMER) 3, 5: 2875-2887.

[2] Callister, William D., David G. Rethwisch. 2009. Materials Science and Engineering an Introduction Eight Edition. US: John Wiley \& Sons, Inc.

[3] Campbell, John. 2003. The New Metallurgy of Cast Metals Castings Second Edition. UK: University of Birmingham.

[4] Pariona, M. M., dan A. C. Mossi. 2005. "Numerical Simulation of Heat Transfer During the Solidification of Pure Iron in Sand and Mullite Molds". J. of the Braz. Soc. of Mech. Sci. \& Eng 27, 4:399-406.

[5] Zamani, Mohammadreza. 2015. "Al-Si Cast Alloys -Microstructure and Mechanical Properties at Ambient and Elevated Temperature". Jönköping : School of Engineering, Jönköping University Department of Materials and Manufacturing.

[6] www.kawasaki.ca/12ninja250r

[7] Choudari. 2014. "Methoding and Simulation of LM 6 Sand Casting for Defect Minimization with its Experimental Validation". 12th Global Congress on Manufacturing and Management 97:1145 - 1154.

[8] Nimbulkar, Sachin L, Rajendra S Dalu. 2016. "Design optimization of gating and feedingsystem through simulation technique forsand casting of wear plate". Perspectives in Science. Pp 44. 